\title{
NGEMPON: THE ROLE-SHARING STRATEGY OF HINDUS AND MUSLIMS IN BHUR BWAH SWAH TEMPLE, KARANGASEM, BALI
}

\author{
I Nyoman Yoga Segara ${ }^{1 *}$ \\ ${ }^{1}$ Institut Hindu Dharma Negeri (IHDN) Denpasar, Bali, Indonesia.
}

\section{ARTICLE INFORMATION}

Submitted : 28 April 2019

Review : 19 August 2019

Accepted : 19 November 2019

Available online: December 2019

\section{KEYWORDS}

Ngempon; Culture Strategy; Role-Sharing; Bhur Bwah Swah temple

\section{CORRESPONDENCE}

*E-mail: yogasegara@ihdn.ac.id

\section{A. INTRODUCTION}

ura (temple) is the name of a holy place for Hindus in Indonesia, although there are additionally other names, such as Kuil for Hindus from India ethnic, Balai Basarah (Dayak Kaharingan in Central Kalimantan), or Candi (Java). Etymologically, pura is originated from Sanskrit, pur, to the locality of the ethnic area it dawns from. Sanjaya (2008) and Subagiasta (2008) distinguished temples based on four sorts of characters, first, family temple. This kind of temple is worshiped by families bound by blood and descendants based on purusha lines (Ind: male). There are quite numerous names of family temples, including Pura kawitan, Pura dadia, Pura panti, and Pura paibon. Second, territorial temple. They are based upon the boundaries of the area where people live. In Bali, each traditional village has some temples that are shared by the community based on the area of residence which consists of Pura desa, Pura puseh, and Pura dalem or known as Pura kayangan tiga. Third, functional temple, namely a temple that is functioned by Hindus who have similar professions or jobs, such as fishermen, traders, or farmers. Fourth, public temples.

\section{A B S T R A C T}

This article is the result of research on how Hindus and Muslims in Tabuan hill, Karangasem could live side by side in harmony. They showed it by becoming pengempon at Bhur Bwah Swah temple. Unlike in general, Muslims also take part in concurrently as pengempon. They actively maintain and carry out the ceremony every six months. The strong will of Muslims to be involved cannot be separated from their historical awareness of the past when they were welcomed and placed in Islamic villages by the king of Karangasem Kingdom. Furthermore, rites are a tool for them to re-dialogue past history to fulfill their needs. It is further used as guides of both religious people to maintain social solidarity. Symbolically, Muslims feel to be an inseparable part of the lives of Hindus since there is a santren in Bhur Bwah Swah temple. It is a sort of place where they perform prayers and celebrate saparan day every year. This research was conducted with a qualitative approach through an interview, observation, and document study techniques and utilize practice theory, precisely concerning the habitus developed by Pierre Bourdieu.

Hindus can visit without distinguishing the origin of the family, traditional village, work, as well as area of origin. Further, each type of Pura above has piodalan or pujawali (Ind: temple festival) which is held every 210 days or every six months.

Functionally, Sanjaya (2008) and Subagiasta (2008) classify temples into two, Pura kahyangan tiga which is built in a village as a holy place to worship God and His manifestations, particularly Sanghyang Tri Wisesa or Tri Murti and Pura Kahyangan Jagat located throughout Bali. This temple is functioned to worship God and His manifestations as the eight guardians of directions. Stuart-Fox (2010: 65) asserts that temples in Bali hold a structure in reliance on three organizational forms, namely locality, ancestry, and irrigation. Though, it seems that Stuart-Fox's opinion has been accommodated into the characterictic of the temple as specified formerly.

Nevertheless, from the characteristic and function of the temple as mentioned above, it eternally has pengempon, a community group or Hindus who have right and obligation to take care and hold sacred ceremonies (Stuart-Fox, 2010). Pengempon is also called penyung-sung or 
pengamong. For instance, pengempon of the family temple is a large family of the temple. Pura kayangan tiga (community in the customary village concerned), Pura swagina (community group based on profession) and public temple (community in province and general Hindus). To be able to take care of temples and hold sacred ceremonies, pengem-pon needs a large amount of money so they will habitually maintain the pelaba land (Ind: land owned by the temple) to make it productive. In addition to the costs obtained from managing the pelaba land, they are further taken from individual contributions and punia funds (Ind: non-binding voluntary donations) as well as a donation from penyungsung.

Pengempon of a temple generally comes from community groups that possess similar identities and notably Hinduism. Though, in Bhur Bwah Swah temple located on Bibis hill, further called Tabuan Hill, Banjar Peninggaran, Seraya Village, Karangasem District, Karangasem Regency, there are unique and compelling facts regarding pengempon since they dissent from prevailing principles. First, as a public temple, Bhur Bwah Swah should only own sacred buildings for Hindus, yet, here, there is a place of worship for Muslims, specifically a small mosque. Muslims in Tabuan hill named it santren. Second, pengempon of Pura Bhur Bwah Swah is reckoned to be a Hindu community group in Karangasem. However, this temple is molded by Muslims. Third, piodalan or pujawali which comemorates on the full moon of Karo (July), Muslims celebrate saparan on Wednesday which is adjecent to the dark moon (a month after full moon). Even every three years, the piodalan and saparan will come together. 2018's festivity was a big celebration, both were held simultaneously. This three uniqueness is appealing to study by exploring the meaning and strategy of ngempon for Hindus and Muslims at Pura Bhur Bwah Swah.

The theoretical perspective encouraged to investigate this problem was a theory of practice, one of them was habitus as proposed by Bourdieu (in Siregar, 2016) for which he referred to as a form of historical epistemology in the framework of revealing the practical relevance of a discourse. As an outcome of history, habitus will design practice, both for individuals and groups, in line with the scheme contained by history. Habitus is present to provide guarantees for past experiences stored in each organism in the form of schemes of perception, thought and action, primarily all formal rules and express norms to ensure the suitability of practices over time (see also Bourdieu, 1977, 1984).

Habitus is used by Bourdieu to ensure that there is a coherence of relations between the concept of society and actors, a connection between individuals and collectivities that allows the development of actors' social production theory and logic of action. Furthermore, Bourdieu said that socialization enhanced a form of integrating class habitus that resulted in individual ownership of the class by reproducing the class as a group that had similar habitus. What is happening at Tabuan hill must also be recognized as the work of Bourdieu's concept of habitus. Within hundreds of years, how they collaborated with Hindus in Tabuan hill was conducted through habituation and continuous socialization thereby social reflexes to maintain harmony could occur unnoticed. This is one of the most important research focuses to be revealed. Thus, habitus can be stated as cultural unconscious which is a historical product since humans were born and interact in social reality. That is, habitus is not nature not merely inherited from biological and psychological science but is the result of learning through experience, perform activities, and community education in the broadest sense.

\section{B. METHOD}

$\mathrm{T}$ o reveal primary and secondary data, this research applied a qualitative approach through an interview, observation, and document study techniques. Considering that Pura Bhur Bwah Swah has a wide area and effortless access to be observed. This research was greatly helped by the informants. As for the key informants (Mr. Mangku Kembar and Mr. Sahrudin) were selected purposively and interviewed since they did not only understand but also undergo the life process in the field. This research was supported by additional informants from the members of the Karangasem royal family as the history of the existence of Muslims living in Tabuan hill and being pengempon of the temple, hence, they cannot be secluded from the role of the kingdom in the past.

This research is expected to be able to attain unique occurrences and render them into narratives that depart from various events and activities, including how the subject's position in social, economic, political, and cultural frames, as with ethnographic-based anthropological research that aims to enrich the sensitivity of researchers, including their experience and awareness (see Spradley, 1979). The source data of the subject explored through interviews and observations was an analytical tool with the intention of capturing the perspective of the subject, and its association with life. Nonetheless, subjects are those who are aware of their own vision and world, as similarly stated by Bruner (1986) who declared that the anthropological approach more focuses on how subjects view their own experiences, including how they seek to understand the world as a subject who experiences and sees it with their own perspective. Research under the theme of tolerance is not something that is obvious to 
describe as what often appears on the surface is distinctive from the hidden. It then became prominent since the researcher had the opportunity to see how the expressions of people encountered so that their social experiences (Hindus and Muslims) in their social connections has a meaningful focus to explore.

Methodologically, this research was inspired by the triad dialectics concept of Berger and Luckman (1966) which states that there are three processes in studying the identity construction in a group and society, namely respecting externalization, objectivation, and internalization which shows that the meaningful and objectivated structure of knowledge (nomos) in reality is to explain individual actions. Another concept that is methodologically valuable to use is symbolic interaction from Blumer (1969) which emphasizes that human social actions generate concepts concerning thoughts, interpretations, actions, role-taking, communication, and action mapping so that they act through words and signals as the manifestations of action of intergroup social.

\section{RESULT AND DISCUSSION}

\section{Muslims in Tabuan Hill: from the Wetu Telu Community to the Five Times of Islam}

$\mathrm{K}$ arangasem is one of the eight major kingdoms in Bali. The entry of Islam to Karangasem could not be sequestered from the entry of Islam into Bali, notably when the Kingdom of Gelgel came to power. Even in this kingdom, for the first time there was the Gelgel village which had a population of Muslims (Parimartha, et al., 2012: 35; see also Fadillah, 1986, 1999; Jelajah Magazine. Issue 08/Yr. 1/March 2010; $12^{\text {th }}$ Edition /Yr. 1/July 2010; Issue $18^{\text {th }} /$ Year $2 /$ January 2011). In his paper, Agung (1979: 2, 3) tried to discuss the re-entry of Islam into Karangasem from various regions, including the motives behind it. This interest in rereading history had been done by various experts (see Tim, 1997/1998: 7-13; Mashad, 2014: 170-178; Kartini [in Basyar, 2016: 101-131]). According to Agung (1979: 3) who is the royal pinisepuh of Karangasem, the history of writing concerning the entry and development of Islam in Karangasem is still inadequate, yet the weakness is reinforced by highly valuable historical relics such as old tombs, ancient inscriptions, and mosques. There are at least four sacred tombs that were believed to be the case for the arrival of Islam, namely the tomb of Sayid Abdulrachman in Buitan Manggis, the tomb of Raden Kyai Jalil in Saren Jawa Budakeling, the tomb of Datu Mas Pakel in Ujung, and the tomb of Datu Seleparang in Tanculung Kecincang.

Agung (1979: 3) states that the written source which has been used presently as a reference is an inscription containing "word" and "piteket" (Ind: advice) which provides information on the placement of Sasak people in Karangasem. The ancient mosque is considered as a guide to the history of the existence of Sasak people in Karangasem in Wijaya's research (1986: 55-56) includes Baiturrahman Mosque in Kecincang, and other ancient mosques located in Ujung, Karang Langko, Nyuling, Subagan Dangin, and other Islamic villages. Some of the ancient mosques even hold bale kulkul (Ind: a pavilium drum, the kentongan will ring out for festival) and bale banjar (Ind: a traditional social function hall, it usually does for meeting), and a pulpit in a full mosque completed with Balinese carvings. Even the Mosques have two or three meru (Ind: a multiple tiered roofs temple architecture). According to Wijaya (1986), this fact shows that the link between Hinduism and Islam has been established for a quite long time. The Karangasem Kingdom is estimated to have a very large influence in building peaceful relations between Hindus and Muslims and paying close attention to Muslims at that time. Kartini (in Basyar, 2016: 105) mentions that the kingdom once helped found the Ampel Mosque which is located 500 meters from the Puri of Karangasem Kingdom.

The kingdom does provide a place to live for Muslims. Mashad (2014: 170) stated that there were around 26 Muslim villages spread out in Karangasem regency. Only one Muslim village that is deemed to be the Javanese origin promptly occupies the Saren Java Village in Budakeling, the rest are Sasak tribal Muslims, Lombok. In the historical record, the Sasak people were brought to Karangasem when the Karangasem Kingdom succeeded in conquering the Kingdom of Pejanggik which at that time controlled the Central Lombok, although this conquest according to Mashad (2014: 170), had taken place long before, namely when Dalem Waturenggong ruled the Gelgel kingdom in Klungkung.

Sasaks who were brought to Karangasem at first were the followers of Wetu Telu. Aziz (2009: 243) affirms that there are two styles of Islam emerged in the Sasak community in Lombok, namely Wetu Telu Islam and Five Times Islam, although this division is not fully accepted. Wetu Telu is a tradition and is not a religion, mainly as a local religion declared by Jahroni and Darmadi (2014). So that the term Wetu Telu Islam is regarded as inappropriate. Aziz and Zuhdi (2006) named it a community which in the study of Rasmianto (2009: 138) is mostly isolated and backward rural communities in life. They generally live in the northern and southern parts of the island of Lombok, and still survive in the village of Bayan, West Lombok Regency and are considered the center of the Wetu Telu civilization. Besides, Zuhdi (2006: 72) who is specialized in researching this community in 
Bayan Village tries to simplify these two variants as a plurality of diversity expressions by categorizing Wetu Telu Islam as traditional religion and Five Times Islam as a divine religion. Though, according to him, this category is not a separate one from each other.

Aziz (2009: 243-244) tells the term Wetu Telu is oftentimes confused with matching it as "time" even though according to this community, the word "wetu" originates from the word "metu" which means "appears" or "comes from". The meaning of the word wetu reveals a belief that all living things appeared (metu) through three kinds of reproduction created by God, namely menganak (giving birth) like humans, menteluk (laying eggs) like birds, and mentiuk (breeding from seeds) like fruits. The Wetu Telu community believes in God who created Adam and Eve as the first humans. Rasmianto (2009: 142, 146) asserts that this community has a telu (three) view of life as if the number is a sacred number. The term "three" in Wetu Telu has nothing to do with religious rituals but an understanding of the origin of human stories.

The existence of Wetu Telu Islam was deemed to have characterized the components of Sasak Islam in Lombok which is unprecedented, even today. Jamaluddin (2011: 64) illustrates the face of Sasak Islam that is peaceful, friendly, and tolerant. This character has become the spirit of Islamization of Lombok. The spread of tolerant even surprisingly accommodating Islam, the belief of vis a vis, practices of religion and local traditions frequently make Islam in Lombok viewed as syncretic Islam. This aspect is influenced by the history of the entry of Hinduism and Buddhism, long before Islam developed in Lombok. Jamaluddin (see also Rasmianto, 2009: 139-141) even suspected that a lot of speculation had grown that stated that Wetu Telu Islam was a Majapahit religion (Hindu-Buddha) that had been colored by Islamic teachings since the Javanese who brought Islam to Lombok still carried Javanese Hindu elements.

This view is further confirmed by the writings of Bartholomew (2001: 96) which states that Wetu Telu beliefs originated from numerous sources, namely Hindu-Majapahit, local traditions, and the influence of Balinese people who ruled Lombok from 1740-1894. As a result of the Hindu-Buddhist influence, Zuhdi (2006: 82) remarked that perhaps the native religion of Lombok people is Sasak Boda, referring to the word Buddha. However, the Islamization of Lombok blown up by the defeat of Majapahit and brought Islamic traders to Eastern Indonesia including Lombok, in the end, was slowly but surely made the Wetu Telu Islam undergo changes. Aziz (2009: 245-246) assumed that as the development of Islam as the majority religion made this community prefer Islam as its religious identity. Various coaching and contributions of tuan guru and scholars, the Wetu Telu com- munity began to implement Islamic teachings perfectly, notably the Five Pillars of Islam.

The Sasak people who adhered to Wetu Telu and lived in Islamic villages since the $16^{\text {th }}$ century in Karangasem were very close to nature and made local wisdom and custom as a way of life. According to the informant Mr. Sahrudin, a takmir mosque or marbot, if there are religious or customary activities in the Puri Kingdom, Sasak Muslims will regularly ngaturang ayah and share their garden produce. Vice versa, if Muslims celebrate a big day, one of them is Eid al-Adha, the kingdom also often donates sacrificial animals.

Despite since independence, chiefly due to the formation of religious leaders, religious assemblies, religious organizations, and the role of the Ministry of Religion of Karangasem Regency, they are now formally no longer adhering to Wetu Telu, Muslims in Tabuan hill remain to carry out the essence of Wetu Telu without banging it against Islam they are currently in. According to informant Mr. Sahrudin, all Muslims in Tabuan hill since the 1980s have adopted Islam Five Times and are practicing obediently the Five Pillars of Islam. However, they continue to carry out some of the customs and cultures adopted in Lombok, such as maulidan and large meals together, which are continued in Tabuan hill through the saparan and megibung ceremonies. The establishment of Masjid Al-lkhlas and the great contribution of $\mathrm{H}$. Nurudin, a donor as well as a figure of Arab descent who migrated from Lombok and were well received by the kingdom has brought the progress of Muslims in Tabuan Hill and its surroundings. Further appreciation went to the role of $\mathrm{H}$. Nurudin, this mosque was visited by many Islamic congregations from abroad, but at the same time they did not refuse to establish kinship with Hindus even becoming the temple pengempon, willing to worship using Balinese traditional clothes, or at least using udeng or destar (Ind: Balinese headgear) and cloth with saput (Ind: cloth tied to the waist).

Now, according to the informant, Sahrudin, followers of Islam in almost all Karangasem, especially in Bukit Tabuan, have embraced Islam by praying five times a day and carrying out the pillars of Islam well. This change is inseparable from their existence outside Lombok and intensive coaching is also carried out by scholars, Muslim leaders and the role of the Ministry of Religion, particularly the Office of the Ministry of Religion in Karangasem Regency. Over time, there are no more Wetu Telu Muslims around Pura Bhur.

\section{Santren and Bhur Temple: "One Bond, Two Beliefs"}

Bhur Bwah Swah temple occupies three locations in Bisbis hill, Seraya, Karangasem. Each temple was then established, namely Bhur 
temple at the bottom, Bwah temple (center) and Swah temple (top). All of these three temple areas are called Bhur Bwah Swah temple and become a unit that cannot be separated. To reach one temple to the next temple, it takes a trip to climb the terrain which is considered difficult because it is still a dirt road and there is no steps access. Climbing becomes even more severe if the rainy season hits. By the local community, Bisbis hill is a twin of Lempuyang hill which also has a temple with the identical structure, specifically the Kahyangan Jagat Lempuyang Temple. Both of these temples are believed to be the two major pillars that guard Karangasem and Bali in general.

As the name implies, this temple is a symbol of the triloka (Ind: three realms), namely the under-world (bhur loka), middle-world (bwah loka), and upper-world (swah loka). Three realms are a holistic concept and represent an unbroken cycle. To mark the strength of each spot, a temple is built, namely in the lower or hillside with Bhur temple, middle (Bwah temple) and upper (Swah temple). Considering that the three temples are a symbol of the three realms concept, all three are united under the name Bhur Bwah Swah temple. Hindu worshipers will worship in stages starting from Bhur temple, then Bwah temple, and finally Swah temple. If they cannot afford to travel with such a heavy field, Hindus will usually pray only in Bhur temple.

Bhur Bwah Swah temple is associated as Puncak Sari Gunung Manik Kembar. Furthermore, this is further termed Bisbis temple since it is at the top of Bisbis Hill, while Bhur temple is named Bhuar Bhuaran temple, Bwah temple as Pasar Agung temple and Swah temple as Puncak Sari Temple Gunung Manik Kembar. However, other names are modified because first, the location or place of each temple has rendered the concept of the Three Realms. Second, the name symbolizes the sacred concept subsists in Hinduism, namely the Three Realms with sections.

There is a small langgar behind the Hindu holy building in Bhur temple. It was the topic and discussion in this research. Muslims who inhabit in the village of Tabuan hill and around Bhur temple refer to the langgar as santren. According to the informant Mr. Sahrudin, said santren had nothing to do with the term pesantren, but the name was proffered by the Sasak Muslims. Santren is only formed bebaturan (Ind: a pile of stones) which is placed at the same area with Bhur temple, not outside the penyengker (Ind: a parapet) that departs the temple from the surrounding environment. Initially, Muslims required to make the santren a separate building and erected outside the penyengker so that it would not be confused with temples. Though, based on mutual agreement between figures from Hindus and Muslims, the santren were left alone in one penyengker.
The agreement was taken then, thus Hindus and Muslims could continue to be united because if it was built outside Bhur temple it would suggest a separation between the two religions even though they had been united both physically and non-physically. The physical structure of the santren or langgar is evident and heretofore it has been maintained despite it is only in the form of bebaturan, but this evidence is symbolic to designate that there has been a very strong touch of Islam. The identical fact was found by Yusuf (2014) and Segara (2018) in Penataran Agung Dalem Jawa Temple, Bunutin, Bangli or better known as Langgar temple. Physically, there is no langgar found in the true meaning of Langgar temple, but the main palinggih building resembles a langgar with nuances of Islamic architecture in Java. The similar form can additionally be read in Djuana's research (2018) roughly the Mecca Temple in Banjar Anyar, Poh Gading Village, Ubung Kaja, Denpasar, where only the touch of Islam is represented in certain parts of the temple building.

There are particular reasons why santren in the temple penyengker are not created magnificently. According to the informant Mr. Sahrudin, they exist because first, the santren were bodily present still and this was enough to be a figure that there is langgar in the penyengker. Secondly, the construction of santren has not become comprehensive langgar to avoid contradictory assumptions. Actually, it is not possible to have two buildings at the same size in one langgar. According to the informant, this agreement was necessitated so as not to become a delicate issue. Third, as a minority, they grant awards to Hindus who are the "owner" of the Bhur Bwah Swah temple. Fourth, even if it was not built, Muslims can still offer prayers at Bhur temple which are conducted outside the penyengker. Fifth, the santren does not require to be developed anymore for Muslims based on permission and agreement with Hindus for they have established a large mosque called Al-Ikhlas that stands majestically about 500 meters before the Bhur temple. This mosque is a pride of Muslims and Hindus in Tabuan hill Village because, in addition to being a symbol of unity, many worshipers also visit not only from remote areas of Bali and some regions in Indonesia, but from abroad, such as Malaysia, India, Pakistan, and Bangladesh.

\section{Ngempon Jointly as a Role Sharing Strategy}

Ngempon jointly can be accomplished with various actions. The most obvious form done by ngaturang ayah when there is piodalan in the temple. Considering that the piodalan temple falls every six months, the pengempon will be busy preparing it even for a month before, depending on the level of the ceremony. There is a piodalan nadi for it is carried out on a large scale, further a 
piodalan alit, which is carried out simply. The size of the piodalan follows the level of ceremonies or means of offering, namely nista (small level), madya (medium level) and utama (major levels). Piodalan called nadi or alit is delimited by these three levels.

The three levels of the ceremony did not diminish the meaning of the ceremony and also did not conquer the social activities of the temple pengempon. Likewise, the pengempon of Hindus and Muslims in Bhur temple. Based on the results of interviews with informants, and strengthened by research data conducted by Seken (2017: 25), the temple pengempon is Hindu krama (Ind: Hindu residents) from Banjar Adat Peninggaran as many as 105 families and Islamic families as many as 90 families. However, if calculated the entire pengempon of Bhur Bwah Swah temple which covers 37 Indigenous Banjar in Seraya Village, it can reach 397 families or with a population of about 228.635 people.

Mr. Sahrudin's information was confirmed by Mr. Mangku Kembar, a stakeholder in the Bhur Bwah Swah temple. According to him, when piodalan came, Muslims have continuously been conducting huge efforts. They did not only distribute the product of the garden but also participated in the celebration, although they did not have to be inside jeroan of the temple (Ind: the inner sanctum). When analyzing harmony in Bali, the ngempon momentum in the view of Halimatusa'diah (2018) is also considered as a huge cultural capital. Some research on the relationship between Hindus and Muslims in Bali shows a similar pattern (Suwindia, et al., 2012; Muchtar, 2013; Pageh, et al., 2013; Subagia, 2014; Karim, 2016; Segara, 2018, 2018).

Based on research data on the entry and survival of Sasak Muslims in Bukit Tabuan as well as their ability to live together, carry out rituals both odalan and saparan and become pengempon together with Hindus in Pura Bhur, it looks clear that sharing roles in a pluralistic society can occur structurally and culturally. Structurally, in the Indonesian context, the function of both formal institutions such as the government (the Ministry of Religion) accommodates to support the survival of religious people who are full of tolerance. The Ministry of Religion even initiated the formation of the Center for Religious Harmony at the central level, while the Forum for Religious Harmony at the provincial and district/city levels (Chapter III Article 8-12 PBM Number 9/8 of 2006), in Hakim's research (in Hakim, 2013; Reslawati in Segara, 2017). Harmony between Hindus and Muslims at Bukit Tabuan is also established because of the cooperation of all parties, including religious institutions, such as the Parisada Hindu Dharma (PHDI) and the Indonesian Ulama Council (MUI), as well as the role of local governments from the village and town levels, as well as the sub-districts and districts Karangasem. Culturally, there is a shared awareness to start from each individual. This condition can occur because Muslims as a minority, peculiarly those living in Muslim villages feel accepted and protected by the majority Hindus in Karangasem.

Thus, Muslims in Tabuan hill who although somewhat minority and seem to "unite" with other Hindus do not inevitably eliminate their identity as devout Muslims because, at the meantime, they have the capacity to do what Piliang said (in Suputra, 2006: 75) as transformative multiculturalism, namely open cultural exchange, crossing of norms and values, fusion of boundaries, and eclecticism in various forms of social, political, and cultural expression. Deeper, the seemingly sloping atmosphere of Hindu and Islamic relations on Tabuan hill can be interpreted as their ability to play cultural strategies by opening up spaces of expression and ensuring that everyone can contribute, notably in order to reduce the dividing barriers between them.

\section{Ngempon Jointly: Adaptation, Habitus, and Collective Awareness}

Based on historical awareness of the value of inter-group unity between Hindus and Muslims, they have been perpetually active, including being creative in carrying out common norms made in the past. Informant Mr. Sahrudin revealed that their existence of the past remained to be told to the younger generation. Oral history is a way for them to constantly see that their existence in the present cannot be sequestered from the past. Piodalan every six months and celebration of saparan every year in the Bhur temple is utilized as a tool to pump up historical awareness from the first generation to the present.

The way Hindus and Muslims in Tabuan hill interpret their history proves Bahktin's thesis (in Rudyansjah, 2009: 42) which asserts that the existence of life is as a process of dialogue between the perpetrator with himself and "the other" in a broad sense, which includes not only other people but also culture, history, and environment around him. Re-reading the cultural strategy carried out by Hindus and Muslims, there has been a continuing transformation thereby their presence can remain to be deciphered actively. The sense of harmony that they live cannot be perceived as static but also can continue to change according to the context of the situation. Consequently, they must therewith advance to care for them intensely through various motions. One that stands out is ngempon jointly and the hallmarks of this culture have become a shared moment that unites the differences between them.

What is interesting, as said by informants both Mangku Kembar from Hindus and Sahrudin 
from Muslims is the adaptive ability and response of Muslims to continue to be able to live together for a very long period of time with the majority Hindus in Bukit Tabuan. The informant Mangku Kembar said when the odalan would arrive, they had already prepared themselves to take part in the ngayah activities and donate their agricultural products. This was also recognized by one of the figures from Puri Karangasem Kingdom who stated that since the beginning of the arrival of Muslims, the castle had always been involved in various activities. Even the purilah placed them around Bukit Tabuan. Over time, they are now not required to go to Puri if there are activities but still establish good relations with Puri and Hindus in general. When referring to Bourdieu's practice theory, one of them through habitus, the highgrade relations that occur do not appear suddenly. There is a set of consecutive socialization carried out by these two religious people, although it must be admitted that Hindus are regarded as "taste of culture" to be shared together as a guideline. In his study, Bourdieu (1979) declares that tastes, nevertheless, he has revealed a unique representation system to certain social groups that define its position in society. However, this taste of culture, imitation, and self-stabilization as a response is a way for everyone to live together. Muslims in Tabuan hill who have realized their existence use selfstabilization to remain to be accepted by Hindus. For instance, in conducting Ngempon they use traditional Balinese clothes or speak balinese fluently. A similar strategy is further carried out by Muslims in Bugis Village, Serangan, Denpasar (Segara, 2018) who use the Balinese language to communicate with Balinese, yet they use Bugis language when communicating with Muslims in their villages. The Sasak Muslims in Sindu village, Gianyar can only use the Balinese language as a daily social language and even more interestingly they join in the banjar adat membership (Segara, 2018). The various strategies implemented may be ethnically based, but entering religious relations sometimes must start with ethnicity, one of which is through language. The kinship and brotherhood between the Balinese are Hindus and the Sasaks are Muslims in Karangasem seem remarkably solid. They create past history to be an opportunity to survive and perform religious, customary, and cultural activities as a source of value to maintain common norms. Ngempon jointly has grown as a medium to reflect on themselves and find out their similarities with others. This state is somewhat comparable to the view of Durkheim (in Saifuddin, 2011: 74) which affirms that religion is the center of culture as it has the greatest power that controls all aspects of human life. Even more decisively, Geertz (in Saifuddin, 2011:
74) called religion not only part of the culture but also the core of culture. As a culture core, religion becomes a life guide, determining the direction and accuracy of life. Without realizing it, Hindus and Muslims through ngempon activities have not only made it a mean to run the religion but also showed their solidarity as a community. Regarding this fact, it can be linked to the view of Durkheim (in Saifuddin, 2011: 29) who stated that fundamental solidarity of a society is formed and maintained by the existence of a system of shared values that have historically been built through tradition. The value system can control the behavior of citizens in a certain direction and unite it in diversity. That unifying power is what Durkheim terms a collective representation. Ngempon jointly is a tradition that is particularly powerful to evolve and maintain harmony and tolerance between Hindus and Muslims in Tabuan hill.

\section{CONCLUSION}

$\mathrm{N}$ gempon is a social-religious activity carried out by Hindus at a temple they tempted. But it is different from pengempon in Bhur Bwah Swah temple who is carried out jointly by Hindus and Muslims. Both of these religious communities can share their roles very well. There are numerous principal reasons why this gathering can be taken mutually, even though they are separated by different beliefs, namely first, Muslims brought by Karangasem Kingdom are adherents of Wetu Telu but it has been remodeled into Islam in global as the formation of ulemas and the Ministry of Religion Office. Secondly, the santren or langgar which is settled inside the Bhur temple has converted a very solid binding between Hindus and Muslims, and that is manifested from Hindu ceremonies and saparan. Third, Hindus and Muslims for hundreds of years succeeded in making ngempon as a cultural strategy to share roles proportionally according to their capabilities. Fourth, a joint engagement between Hindus and Muslims can be deciphered as a way for Muslims to adapt and respond to their existence, both because of history and life in the present.

\section{E. ACKNOWLEDGMENTS}

$T$ he author would like to thank Mr. Ahmad Saleh as the faithful gatekeeper during the study, as well as Mr. Mangku Kembar and Mr. Sahrudin as the key informants. 


\section{REFERENCES}

Agung, A.A.G. Putra. (1979). "Sejarah Masuknya Islam di Karangasem Bali". A Paper of National Seminar III. Universitas Udayana. Page 1-18.

Aziz, Ahmad Amir. "Islam Sasak: Pola Keberagamaan Komunitas Islam Lokal di Lombok". Millah Journal. Vol VIII No. 2 February 2009. Page 241-253.

Berger, Peter L. \& Thomas Luckmann. (1966). The Social Construction of Reality: A Treatise in the Sociology of Knowledge. Garden City, New York.

Bourdieu, Pierre. (1977). Outline of a Theory of Practice. Cambridge: Cambridge University Press.

Bourdieu, Pierre. (1984). Distinction. Cambridge: Polity Press.

Bortholomew, John Ryan. Alif Lam Mim: Kearifan Masyarakat Sasak. Translated by Imron Rosyidi. (2001). Yogyakarta: Tiara Wacana.

Bruner, Edward. (1986). Experience and Its Expressions dalam Bruner (ed) The Anthropology of Experience. Chicago: University of Illinois.

Blumer, Herbert. (1969). Symbolic Interaction. New York: Prentice Hall.

Djuana, I Nyoman dan Ni Made Surawati. "Pura Mekah di Banjar Anyar Desa Poh Gading, Ubung Kaja, Kota Denpasar (Analisis Struktur, Historis dan Fungsi)". Widya Wretta Journal. Vol. 1 Nomor 1, April 2018. Page: 10-23.

Fadillah, Moh Ali. (1986). Makam-Makam Kuno di Pulau Serangan dan Beberapa Makam di Kabupaten Badung, Bali. Suatu Kajian Arkeologis. Denpasar: Skripsi, Universitas Udayana.

Fadillah, Moh Ali. (1999). Wrisan Budaya Bugis di Pesisir Selatan Denpasar. Nuansa Sejarah Islam di Bali. Jakarta: The Ministry of Education and Culture, National Archaeological Research Center.

Halimatusa'diah. "Peranan Modal Kultural dan Struktural dalam Menciptakan Kerukunan Antarumat Beragama di Bali”. Harmoni Journal. Vol. 17 No. 1 Januari-April 2018. Page 43-65.

Hakim, Bashori A. "Peran Pemerintah Daerah dan Kantor Kementerian Agama Provinsi Bali dan Kota Denpasar dalam Pemeliharaan Kerukunan Umat Beragama" in Bashori A. Hakim (ed). (2013). Peran Pemerintah Daerah dan Kantor Kementerian Agama. Jakarta: The Religious Life Research and Development Center, Development Research and Training Agency of the Ministry of Religion.

Jahroni, Jajang dan Dadi Darmadi. "Agama/Kepercayaan Islam Wetu Telu di Bayan, Lombok Utara (NTB)" in Suhanah (ed). (2014). Dinamika Agama Lokal di Indonesia. Jakarta: Center for Religious Life Research and Development, Research and Development Agency, Ministry of Religion.

Jamaluddin. "Islam Sasak: Sejarah Sosial Keagamaan di Lombok (Abad XVI-XIX)". Indo-Islamika Journal. Volume 1 No. 1, 2011/1432. Page 63-88.

Karim, M. Abdul. "Toleransi Umat Beragama di desa Loloan, Jembrana, Bali (ditinjau dari Perspektif Sejarah)". Analisis Journal. Volume XVI, No. 1, June 2016. Page: 1-32.

Kartini, Indriana. (2016). "Dinamika Kehidupan Sosial Budaya Muslim Karangasem" in Masyarakat Muslim Bali di Klungkung, Karangsem dan Bangli (editor Hamdan M. Basyar). Yogyakarta: Calpulis.

Laporan Napak Tilas Majalah Jelajah. "Segitiga Emas Dakwah Islam Pulau Dewata". Jelajah Magazine. Edition 08/Year. 1/March 2010.

Laporan Napak Tilas. "Jejak Emas Islam Ujung Timur Bali. Benteng-Benteng 'Nyawa' Puri Karangasem". Jelajah Magazine. Edition 12/Year. 1/July 2010. Page 04-09.

Laporan Napak Tilas. "Tak Ada Kudeta terhadap Kerajaan Bali". Jelajah Magazine. Edition 18/Year. 2/January 2011. Page 04-09.

Mardotillah, Mila dan Dian Mochammad Zein. "Silat: Identitas Budaya, Pendidikan, Seni Bela Diri, dan Pemeliharaan Kesehatan”. Jurnal Antropologi: Isu-Isu Sosial Budaya. December 2016 Vol. 18 (2): 121-133.

Mashad, Dhurorudin. (2014). Muslim Bali Mencari Kembali Harmoni yang Hilang Jakarta: Pustaka AlKautsar.

Muchtar, Ibnu Hasan. "Peran Kelompok Keagamaan dalam Pemeliharaan Kerukunan Umat Beragama (Studi Kasus Desa Adat Angantiga, Petang, Badung, Bali)”. Harmoni Journal Vol 12. No. 3 September-December 2013. Page 136-152.

Munandar, Agus Aris. (2005). Istana Dewa Pulau Dewata: Makna Puri Bali Abad ke 14-19 M. Depok: Komunitas Bambu.

Parimartha, I Gede, dkk. (2012). Bulan Sabit di Pulau Dewata. Jejak Kampung Islam Kusamba-Bali. Yogyakarta: CRCS.

Pageh, I Made, Wayan Sugiartha, Ketut Sedana Artha. "Analisis Faktor Integratif Nyama Bali-Nyama Selam, Untuk Menyusun Buku Panduan Kerukunan Masyarakat di Era Otonomi Daerah". Jurnal IImu Sosial dan Humaniora. Vol. 2, No. 2, October 2013: 239-248.

Rasmianto. "Interrelasi Kiai, Penghulu dan Pemangku Adat dalam Tradisi Islam Wetu Telu di Lombok". el-Harakah Journal. Vol. 11, No. 2, Year 2009. Page 138-154. 
Reslawati. "Hindu di Bali: Keseimbangan Hidup melalui Agama, Budaya dan Adat (Studi pada Klan Pura Keluarga di Pura Kawitan Dalem Pande Majapahit di Denpasar)" in I Nyoman Yoga Segara (ed). (2017). Dimensi Tradisional dan Spritual Agama Hindu. Jakarta: Research Center for Community Guidance on Religion and Religious Services, Research and Development Agency and Education and Training Ministry of Religion.

Rudyansjah, Tony. (2009). Kekuasaan, Sejarah, dan Tindakan. Sebuah Kajian Tentang Lanskap Budaya. Jakarta: Rajawali Press.

Sanjaya, Putu. (2008). Acara Agama Hindu. Surabaya: Paramita.

Saifuddin, Achmad Fedyani. (2011). Catatan Reflektif Antropologi Sosialbudaya. Jakarta: Institut Antropologi Indonesia.

Segara, I Nyoman Yoga. "Pura Langgar: Representation of Hindu and Islamic Relation in Bunutin, Bangli". Proceedings of International Seminar Bali Hinduism, Tradition, and Interreligious Studies. Universitas Hindu Indonesia, 2018. Page 185-191.

Segara, I Nyoman Yoga. "The Cultural Treasures of Kampung Bugis in the Customary Village of Serangan, Denpasar". Journal Heritage Nusantara. Vol. 7 No 1, 2018. Page. 94-118.

Segara, I Nyoman Yoga. "Kampung Sindu: Jejak Islam dan Situs Kerukunan di Keramas, Gianyar, Bali". Jurnal Lektur Keagamaan. Vol. 16, No.2, 2018. Page 315-346.

Seken, I Ketut. (2017). Pura Bhur Bwah Swah dalam Dua Dimensi Keagamaan (Hindu-Islam) di Karangasem. Research Report. STKIP Agama Hindu Amlapura.

Siregar, Mangihut. "Teori "Gado-gado" Pierre-Felix Bourdieu”. Jurnal Studi Kultural. (2016) Volume I No.2: 79-82.

Stuart-Fox, David J. (2010). Pura Besakih. Pura, Agama, dan Masyarakat Bali. Terjemahan Ida Bagus Putra Yadnya dari Pura Besakih: Temple, religion and society in Bali. Denpasar: Udayana University Press.

Subagia, I Nyoman. (2014). "Realisasi Toleransi Umat Hindu dan Islam dalam Aktivitas Keagamaan di Desa Keramas Kecamatan Blahbatuh Kabupaten Gianyar". Research Report of IHDN Denpasar.

Subagiasta, I Ketut. (2008). Pengantar Acara Agama Hindu. Surabaya: Paramita.

Suputra, Pande Made. "Identitas Etnis dan Otonomi Daerah dalam Membangun Multikulturalisme di Indonesia" in IBG Pujaastawa, ed. (2006). Wacana Antropologi. Denpasar: Pustaka Larasan.

Suwindia, I Gede, Machasin, dan I Gede Parimartha. "Relasi Islam dan Hindu Perspektif Masyarakat Bali". Al-Ulum Journal Volume. 12, No. 1, June 2012. Page 53-76.

Tim Peneliti. (1997/1998). Sejarah Masuknya Islam di Bali. Denpasar: Project Guidance Section and Islamic Religion Da'wah of Bali Province.

Wijaya, Nyoman. (1986). "Cahaya Kubah di Ujung Timur Kahyangan: Studi Perkembangan Islam di Kabupaten Karangasem 1950-1980". Skripsi. Yogyakarta: Faculty of Literature Universitas Gadjah Mada.

Yusuf, Stephanie Arvina. (2014). "Konsep Bentuk Arsitektur Pura Langgar pada Komplek Pura Penataran Agung Dalem Jawa di Desa Bunutin, Bangli-Bali”. Skripsi. Bandung: Bachelor Program in the Faculty of Engineering Architectural Study Program, Universitas Katolik Parahyangan.

Zuhdi, Muhammad Harfin. "Parokialitas Adat Terhadap Pola Keberagamaan Komunitas Islam Wetu Telu di Desa Bayan Lombok". Jurnal Kontekstualitas. Jurnal Penelitian Sosial Keagamaan. Vol. 21 No. 2. Dec 2006. Page 71-94. 